\title{
LIST OF COLEOPTERA
}

COLLECTED EY A, S, PACKARD, JUN., AT CARIBOU ISLAND, LABRADOR, STRAITS OF BELLJI ISLE.

The Coleoptera here enumerated, and named several years since by Dr. LeConte, were collected by me during the summer of 1860 at Caribou Island while a member of the Williams College expedition to Labrador and Greenland, under the direction of Prof. P. A. Chadbourne. This is an incomplete list of the Coleoptera of Labrador; and in a subsequent expedition with my friend, Wm. Bradford, the artist, to Hopedale, Labrador, many more forms, as yet not named, were collected.-A. S. P.

Gyrinus, not determincd.

Agabus punctulatus, Aubé.

" lavidorsus, Lec.

" semipunctatus, Kirby.

" subfasciatus, Lec.

" infuscatus, Aubé.

Colymbetes sculptilis, Harris.

" picipes, Kirby.

Hydroporus tenebrosus, Lec.

Silpha Lapponica (Linn.).

Creophilus villosus, Grav.

Amara similis, Lec. (Stereocerus sinilis, Kirby).

Amara near melanogastrica, Esch., perhaps brunnipennis, Dej.
Calcthus confusus, Lec.

Bladius, not determined.

Ips sanguinolentus, Oliv.

Byrrhus Americanus, Lec.

" Kirbyi (picipes, Kirby).

Eanus vagus, Lec. (Limonizs v'agus, Lec.).

Eanus maculipennis, Lec., n. sp.

Philhydrus bifidus, Lec.

Podabrus mandibularis (Acmcops proteus, Lec., Lepr. proteus, Kirby.)

Atomaria, not determined.

Criocephatus agrestis, Kirby.

Leptura, n. sp.

\section{BOOKS RECEIVED.}

Glimpses of Nature, a Magazine of Natural History in all its branches. Edited by Samuel M. Maxwell (Vol. i, No. 1), Mauch Chunk, Pa., June, I 870 . A new and neatly-printed periodical, to which we wish all possible success.

First Annual Report of the American Museum of Natural History. January, 1870, New York.

Notes on Graptas C-aureum and interrogationis, $F_{a l} b$, and Descriptions of new species of Diurnal Lepidoptera found within the United States. By Wm. H. Edwards. Among the eighteen new species described in the latter paper is one, Pieris Virginiensis, that has been taken in London, Ont., by Mr. Saunders. 